\title{
LEAGILE EVALUATION OF MANUFACTURING ORGANIZATION
}

\author{
S.Aravind Raj ${ }^{1}$, K.Jayakrishna ${ }^{2}$, K.Pandiyan ${ }^{3}$ \\ ${ }^{1}$ Assistant Professor, CARE School of Engineering, \#27 Thayanoor Village, Tiruchirappalli-620 009,Tamil Nadu, \\ India \\ ${ }^{2}$ Assistant Professor, CARE School of Engineering, \#27 Thayanoor Village, Tiruchirappalli - 620 009,Tamil Nadu, \\ India \\ ${ }^{3}$ Post Graduate Student, Department of Production Engineering, National Institute of Technology, Tiruchirappalli- \\ 620 015, Tamil Nadu India
}

\begin{abstract}
Recent manufacturing system requires identifying the needs of their customer base to maintain the group of customers'. This study focuses the combined approach of lean and agile principles as 'leagile' to focus about the wastages across manufacturing processes and to find the responsiveness of the firm to the customer. The study has been done in a manufacturing firm and assessment of the firm is done by using fuzzy approach.
\end{abstract}

Keywords: Manufacturing; Leagile; Responsiveness

\section{INTRODUCTION}

Manufacturing firms experiences highly volatile market due the technological updates, customer needs, competitor's product and pricing. To overcome all the related issues and to be successful in the market manufacturing firms have incorporated qualitative techniques. This study focuses towards the leagile evaluation of manufacturing firm using a leagile model. This model comprises of criteria which is related to both lean and agile manufacturing concepts. The assessment of the firm has been done and its useful to know the existing position of the firm. Further this study will be useful to identify the technical gaps prevailing in the firm.

\section{LITERATURE REVIEW}

Naylor et al. [1] have initiated a new concept called 'leagility' by merging both lean and agile principle. The authors have assessed the performance of leagility if the supply chain. Jones et al. [2] have explored their work on assessing the performance of supply chain by considering the market demands. Chan et al. [3] presented their work related to outsourcing and leagility principles to succeed in the current market. The article proposes a new model based on leagility principles which include the practice of integrated planning management.

\section{METHODOLOGY}

Figure 1 shows the research study methodology. The study initiated by reviewing articles related to lean, agile and leagile manufacturing. The case study has been done in small scale manufacturing firm. The assessment has been done using fuzzy approach. The leagile index of the firm has been computed and results were used to identify the weaker areas of the firm.

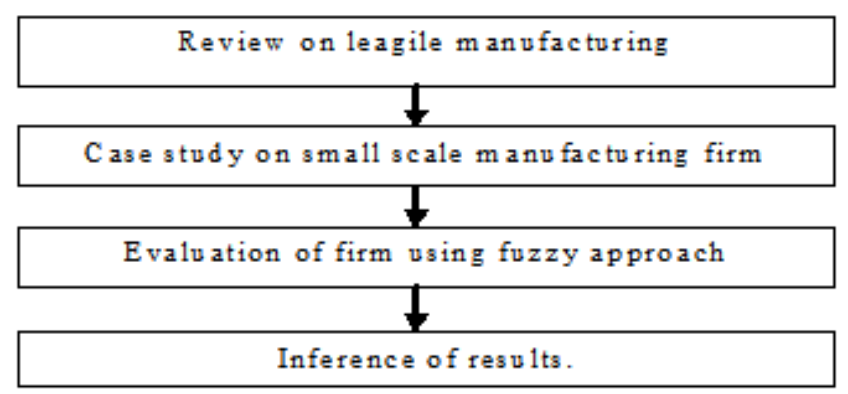

Fig -1: Study Methodology

\section{CASE STUDY}

The case study has been done in small scale manufacturing firm located in Tiruchirapalli, Tamil Nadu, India. The manufacturing firm experiencing uncertainty due to current market scenario, their exists the need of leagile assessment in the firm to know the vital areas for development. The leagility index is denoted by I. The index has been found using the product of overall assessment factor $\mathrm{R}$ and overall weight $\mathrm{W}$.

$$
\mathrm{I}=\mathrm{W} \times \mathrm{R}
$$

The assessment has been classified into five different categories. . $I=\{10,8,6,4,2\}(8-10$ represents 'extremely leagile', 6-8 represents 'leagile', 4-6 represents 'generally leagile', 2-4 represents 'not leagile' and less than 2 represents 'extremely not leagile') [3]. Table 1 shows the excerpt of leagile model and fuzzy scores pertaining to 'Productivity' criterion

Table -1: fuzzy scores pertaining to 'Productivity' criterion

\begin{tabular}{|l|l|l|l|l|l|l|l|}
\hline $\mathbf{I}_{\mathbf{i}}$ & Attribute & $\mathbf{I}_{\mathbf{i j}}$ & $\mathbf{E}_{\mathbf{1}}$ & $\mathbf{E}_{\mathbf{2}}$ & $\mathbf{E}_{\mathbf{3}}$ & $\mathbf{E}_{\mathbf{4}}$ & $\mathbf{E}_{\mathbf{5}}$ \\
\hline 0.1 & $\begin{array}{l}\text { Production } \\
\text { rate }\end{array}$ & 0.3 & 7 & 7 & 8 & 8 & 9 \\
\hline
\end{tabular}




\begin{tabular}{|l|l|l|l|l|l|l|l|}
\hline $\mathbf{I}_{\mathbf{i}}$ & Attribute & $\mathbf{I}_{\mathbf{i j}}$ & $\mathbf{E}_{\mathbf{1}}$ & $\mathbf{E}_{\mathbf{2}}$ & $\mathbf{E}_{\mathbf{3}}$ & $\mathbf{E}_{\mathbf{4}}$ & $\mathbf{E}_{\mathbf{5}}$ \\
\hline \multirow{3}{*}{} & Cost & 0.3 & 8 & 7 & 6 & 8 & 7 \\
\cline { 2 - 8 } & Cycle time & 0.4 & 7 & 6 & 7 & 8 & 9 \\
\hline
\end{tabular}

Weight pertaining to 'Productivity' criterion $\quad \mathrm{W}_{3}=(0.3$, $0.3,0.4)$

Assessment Vector pertaining to 'Productivity' criterion is given by

$$
\mathrm{R}_{3}=\left[\begin{array}{lllll}
7 & 7 & 8 & 8 & 9 \\
8 & 7 & 6 & 8 & 7 \\
7 & 6 & 7 & 8 & 9
\end{array}\right]
$$

Index pertaining to 'Outsourcing' is given by

$$
\begin{gathered}
I_{3}=W_{3} \times R_{3} \\
I_{3}=\left(\begin{array}{lllll}
7.3 & 6.6 & 7.0 & 8.0 & 8.4
\end{array}\right)
\end{gathered}
$$

The calculation further extended up to secondary and tertiary level, leagile index has been computed.

$$
\mathrm{I}=7.56 \in(6,8)
$$

The value of leagility Index is found to be 7.56 on Likert's scale. So this value represents that the case company is $75.6 \%$ leagile in nature and scope for improvement exists in the case organization. The results imply the current position of the leagility in the firm as 'Average'.

\section{CONCLUSIONS}

This study is useful to find the leagile index of the small scale manufacturing firm considering both lean and agile manufacturing. Results clearly show that index of the firm is $75.6 \%$ and technical gaps exist in the firm.

\section{ACKNOWLEDGMENTS}

I sincerely thank Mr. B. Prative Chend, CEO, CARE Group of Institutions, Trichy for his continuous encouragement towards research \& development in innovative manufacturing arena.

\section{REFERENCES}

[1]. Naylor, J.B., Naim, M.M and Berry, D. (1999) Leagility: Integrating the lean and agile manufacturing paradigms in the total supply chain. International Journal of Production Economics, 62, 107 -118.

[2]. Jones, R.M., Naylor, B. and Towill, D.R. (2000) Lean, agile or leagility? Matching your supply chain to the marketplace. International Journal of Production Research, 38, 4061-4070.

[3]. Yang, S.L. and Li, T.F., (2002) Agility evaluation of mass customisation product manufacturing. Journal of Materials Processing Technology,129, 640-644.

\section{BIOGRAPHIES}

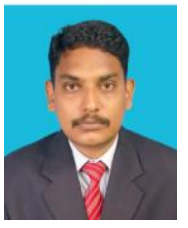

S.ARAVIND RAJ has working as Assistant Professor at Department of Mechanical Engineering at Care School of Engineering, Tiruchirappalli, Tamil Nadu, India. He has published eight papers in international journals and 16 papers in international conferences. His research areas include Agile Manufacturing, Lean Manufacturing and Supply Chain Management.

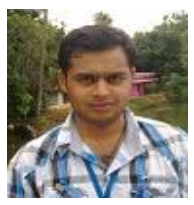

K.JAYAKRISHNA has working as Assistant Professor at Department of Mechanical Engineering at Care School of Engineering, Tiruchirappalli, Tamil Nadu, India. He has published eight papers in international journals and 16 papers in international conferences. His research areas include Sustainable Manufacturing, and Product Development

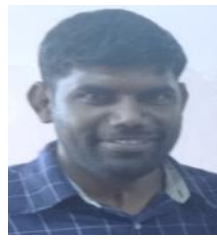

K.PANDIYAN has pursuing his Post graduate degree in Manufacturing Technology from National Institute of Technology, Tiruchirappalli, Tamil Nadu, India. His research areas include industrial engineering and optimization. 